\title{
Formation of Beach Profile with the Design Criteria of Seawalls
}

\author{
Edward Ching-Ruey LUO \\ Department of Civil Engineering, National Chi-Nan University.227 Gan-Cherng St. Taichung 40843, Taiwan \\ *Corresponding Author: edward.luo@msa.hinet.net
}

Copyright $@ 2014$ Horizon Research Publishing All rights reserved.

\begin{abstract}
When wave energy builds up, beach berm and even dunes are quickly eroded with this material being removed offshore to form a bar parallel to the beach. It proceeds seawards during the course of the storm to reach some ultimate location prior to being dismantled and moved back to the beach by subsequent swell. There is difficulty in defining the steepness associated with storm, although it has commonly been accepted that steeper waves often produce a bar or a barred beach bar position and its crest height for a given storm condition. Therefore, criteria for the formation of bar and berm profiles respectively, need to be clarified.. In this paper, the available experimental data of large wave tank (LWT) from U.S. Army Crops of Engineering and Japanese Central Research Institute of Electric Power Industry are used to construct a new relationship. Finally, criteria for bar and berm formation and seawalls design are found, and new criteria form are quite simple and widely applicable.
\end{abstract}

Keywords Beach Profile; Bar; Berm; Wave Run-up; Wave Run-down; Seawall

\section{Introduction}

When people buy a home or other property by the seashore, they may not realize that nature may radically alter the value of their investment. In addition to dangers from storms (e.g., Hurricane Katrina) and other disasters (e.g., tsunami), waves are slowly and inexorably altering the shoreline, eroding material from some places and carrying it to other places. Each wave has a small effect, but they keep coming hour after hour, day after day, year after year. Significant changes in the shoreline (10's of meters) can occur within a human lifetime.

Beach sediments are composed of whatever sediments are available locally: sand, cobbles, gravel, coral fragments, shell fragments, etc. Beach sediments are characterized by the kind of material that they are made out of, their size, their shape, and sorting (well sorted: about the same size and shape, poorly sorted: many different sizes and shapes).
Sediments are "eroded" (carried, transported): carried to the shoreline by running water (rivers), and pushed along the shoreline by waves (long-shore transport). Sediments are also produced at the shoreline itself by weathering and erosion of the rock of the shoreline. "High energy" water (fast-flowing rivers and strong waves) can lift and carry more sediment sand larger, heavier sediments than "low energy" water. Once the water calms, the larger, heavier sediments are dropped (deposited), but smaller, lighter sediment continue their journey, which separates ("sorts") the sediments. The smallest sediments (mud, clay, silt) sink very slowly, so they are easily carried and only settle in very calm water. Sand can be carried by stronger flows; even though it drops quickly to the bottom, it is picked again and again. The shape of a beach is primarily affected by wave conditions and tide levels. Waves can both push sand onto the beach from the ocean and drag sand back into the ocean. Typically, a mound or hill of sand (the "berm") builds up along the shoreline. At high tide, this is the only part of the beach that is above water, so the beach slope appears quite steep. As waves push into the shoreline, they erode a flat area in front of the berm called the "low tide terrace." At low tide, this flat area is exposed, and the beach appears less steeply sloped (seen Figure 1).

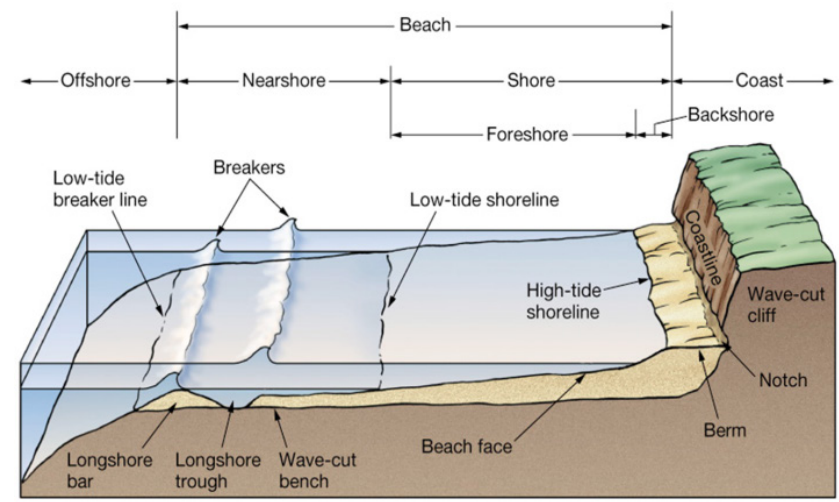

Figure 1. The Feature of the Beach Profile

During summer (Figure 2), waves tend to be smaller and have a longer period (and wavelength), because there are fewer, weaker nearby storms and the stronger storms are 
farther away (in the other hemisphere where it is winter). Since wave crests arrive at the shoreline less frequently, the water of the breaking waves has time to soak into the beach sand and can work its way back to the ocean through the sand. Thus, waves push sand up the beach, and then it remains on the beach. During winter, wave crests crash against the beach so frequently that the sand becomes saturated with water, and more water flows back into the ocean over the sand (and under the incoming waves, hence the term "undertow"), often dragging more sand back into the ocean than they push up the beach. Thus, wintertime beaches (Figure 3) often have less sand, which sometimes exposes the larger rocks beneath the sand. The sand, though, is not permanently removed from the beach: it will be pushed up and out of the ocean again during the spring and summer, only to be removed again during the fall and winter.
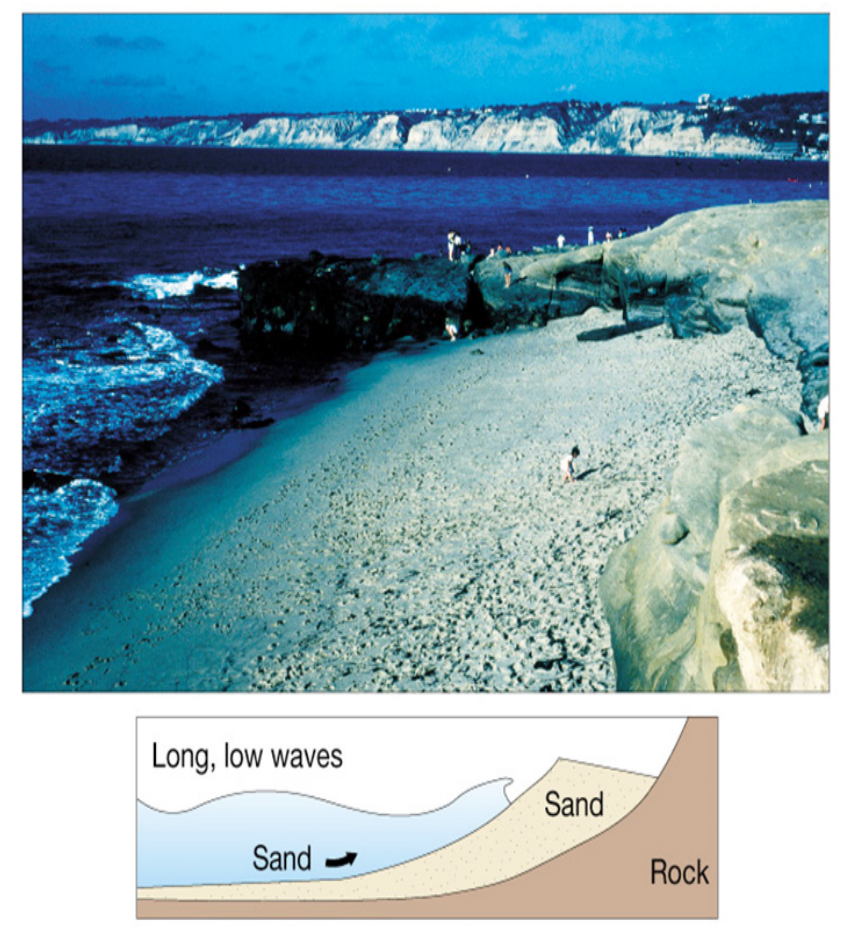

Summertime beach (fair weather)

Figure 2. The Feature of Summertime Beach

According to Sunamura and Horikawa [1], they classified beach profiles into three types (Figure 4): type A as storm or winter beach which forms erosion bars to the sea direction; type $\mathrm{B}$ as transitional beach and type $\mathrm{C}$ as normal or summer beach. which results deposition beams on the land-direction, where $\boldsymbol{H o}, \boldsymbol{D}$ and $\boldsymbol{L o}$ are wave height, sediment diameter (D50 used) and wave length in the deep sea respectively, while the foreshore slope as $\tan \beta$. The most significant concept in nearshore processes is that of the equilibrium profile of beach and it dictates that beaches respond to wave forcing by adjusting their own form to an equilibrium or constant shape attributable to a given incident wave, such as the well-known seasonal changes in response to high waves of winter (Figure 5) and the lower ones of summer (Figure 6) in seasonal equilibrium with the changing character of the prevailing waves. A equilibrium profile have to be defined as one along which the local, time-averaged, cross-shore sediment transport is zero everywhere, as are the gradients in longshore transport. However, the attributes of wave forcing that drive sediment transport, and the mechanics of the beach response are needed to furthermore study. To consider the equilibrium profiles in terms of the very real difference in forcing from deep water to the breakpoint by shoaling waves, as contrasted with that by the breaking waves and their bores in the surf zone. These two discontinuous portions of the profile (Figure 7) are referred to here as the "shorerise" and "bar-berm" segments of the beach profile.
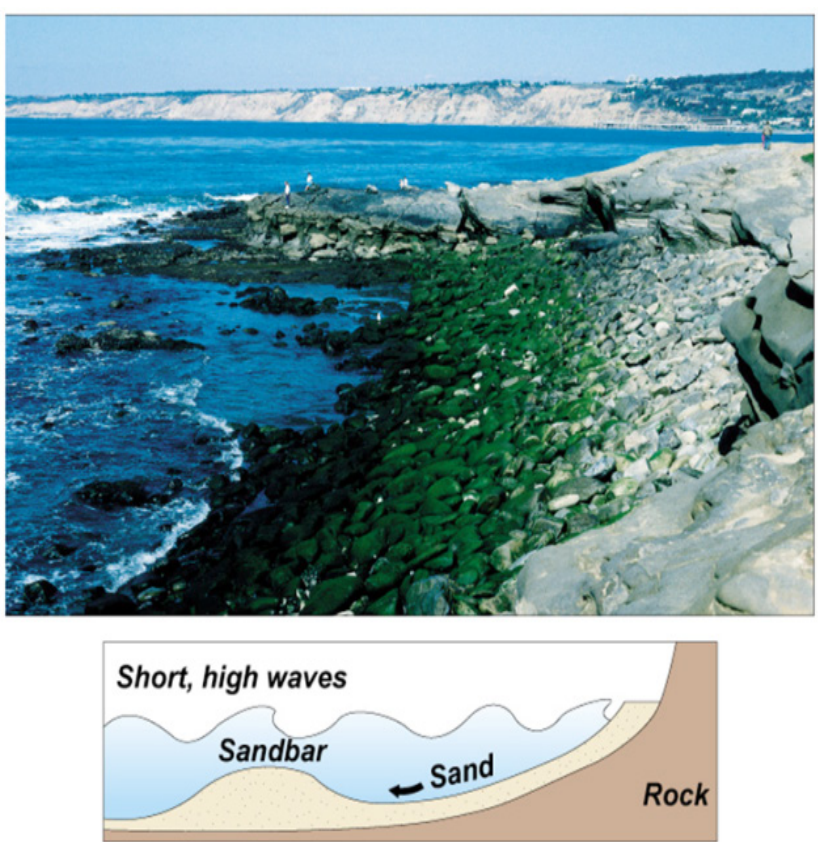

Wintertime beach (storm)

Figure 3. The Feature of Wintertime Beach 
Ho/ Lo

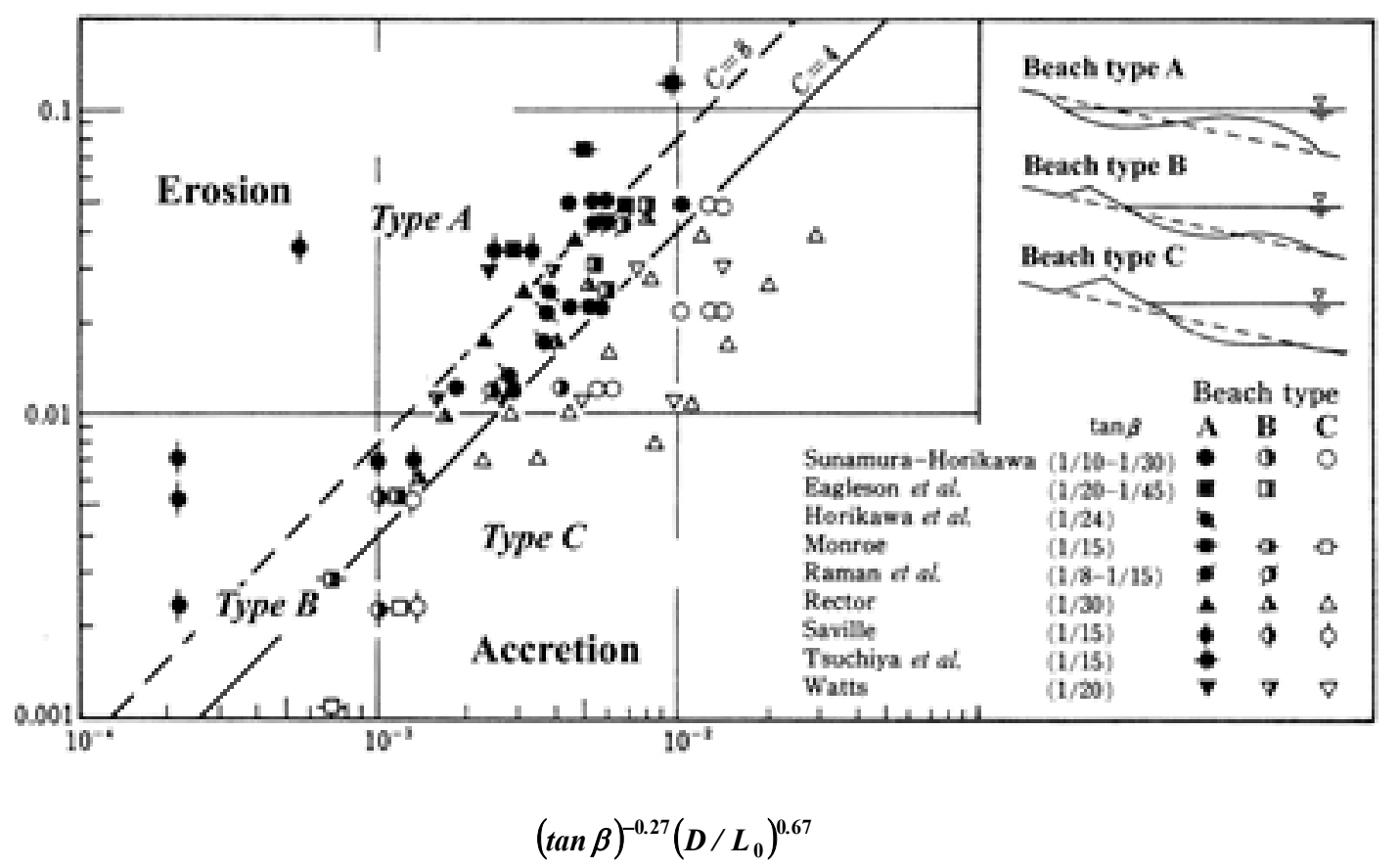

Figure 4. Beach Profile Classification

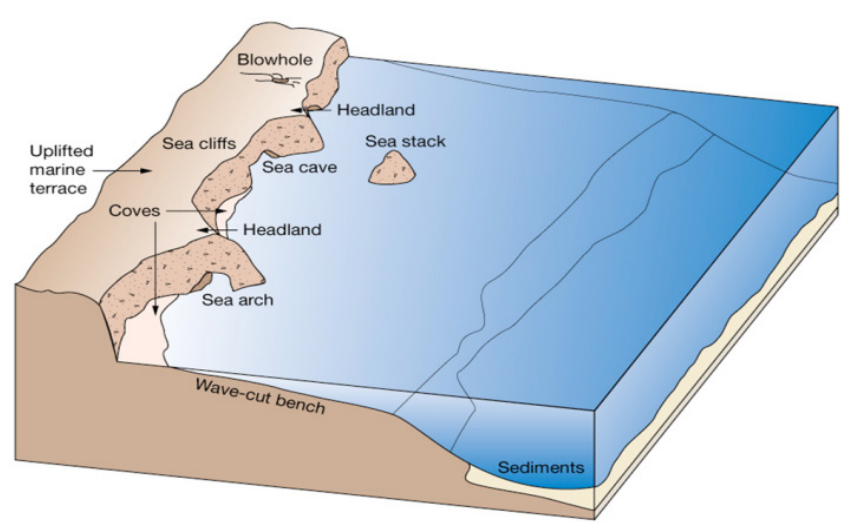

Figure 5. The Feature of Erosional Shores

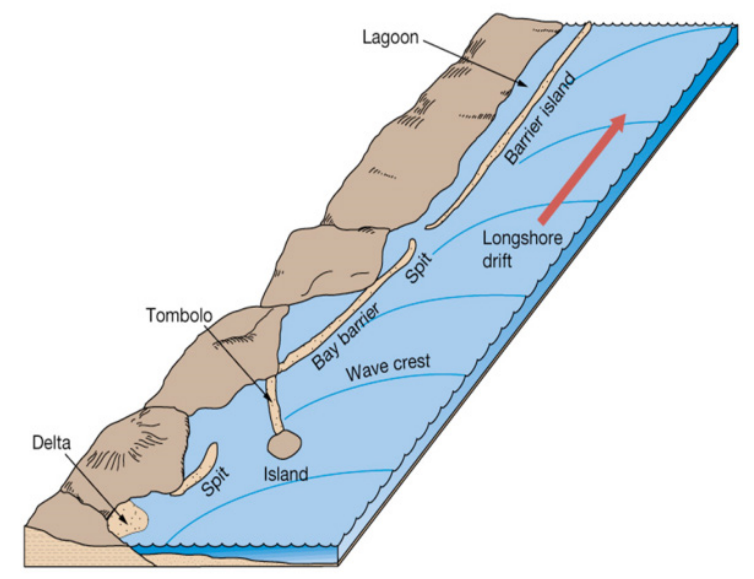

Figure 6. The Feature of Depositional Shores

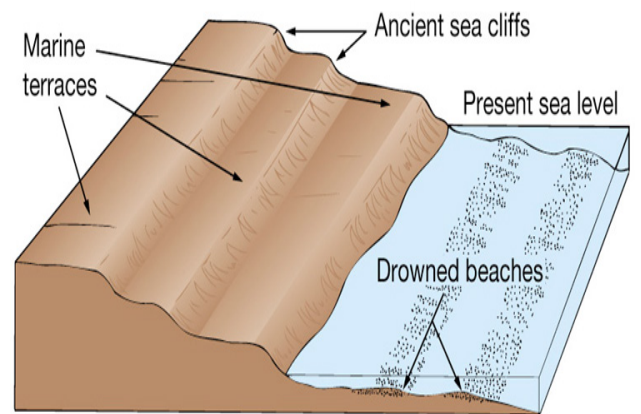

Figure 7. The Feature of Submerging Shorelines

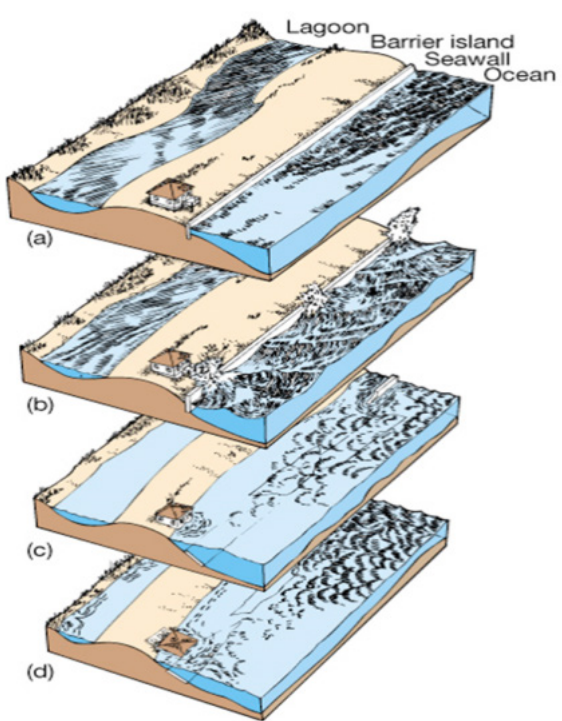

Figure 8. Procedures of Erosion and Destroy due to Seawalls 
Seawalls are walls built along the coast to keep waves from eroding it, typically to protect a building. Waves eventually erode the seawall (just like they erode the land), so it needs constant maintenance. If funds run out, then debris from the seawall litters the beach, including rusty pieces of iron that were used to bind the seawall together. The shoreline on either side of the seawall continues eroding, of course. The seawall can actually help the shoreline on each side erode, because the seawall's ends reflect waves towards the land on either side. As the shoreline to the side of the seawall erodes, the seawall has to be extended (costs more \$), because more of the building's property is exposed to the sea. This will never end, costing more and more money. Worse yet, seawalls (Figure 8) can cause the beach in front of the seawall to erode. Wave energy is reflected from ("bounces off") the seawall towards the sand in front of the seawall, pushing it out into the ocean. As the sand is removed from the base of the seawall, the land that the seawall is built on is exposed to the waves. The waves erode the land beneath the seawall, causing they seawall to collapse (Figure 9).

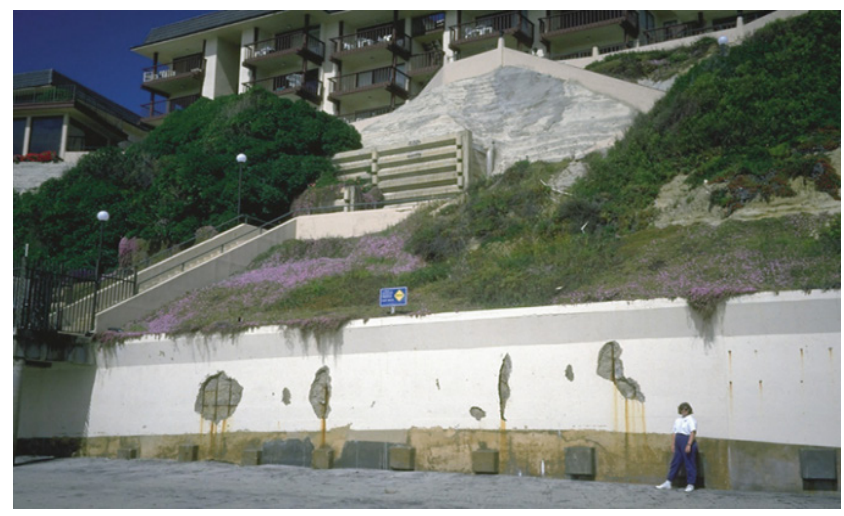

Figure 9. The Damages of Built Seawalls

\section{Classifications of Bar-Berm}

Bagnold[2], Keulegan[3], Larson and Kraus[4], and Dean[5] showed the classical description of bar formation includes onshore transport outside the breakpoint and offshore transport inside, associated with the changes in forcing at the breakpoint and accordingly with the assumption to fit by separate curves matched as the bar. Shepard and LaFond[6] presented the first study of profile changes and cross-shore transport on an ocean beach, meanwhile, Evans[7] published a study of bar formation along the shores of Lake Michigan. Keulegan and Krumbein[8] concluded that a shoaling solitary wave would result in a stable profile of the form:

$$
\mathrm{h}=\mathrm{Ax}{ }^{\mathrm{m}}
$$

where $\mathrm{h}$ is depth, $\mathrm{A}$ is a constant of proportionality, $\mathrm{x}$ is distance from shore, and the exponent $m$ has a value of $4 / 7$. Brunn[9] made an extensive study and found the averaged values $A$ and $m$ of 0.20 and $2 / 3$ for the North Sea coast of
Denmark, and 0.22 and 2/3 for Miaaion Beach, San Diego respectively. Dean[10] found the average beach profile along the Outer Banks of North Carolina with values of A and $m$ of 0.13 and $2 / 3$. While we consider the effects of bed with the sediment of the mean diameter, $m$ becomes $2 / 5$ as the report of Dean[5]. Inman, Elwany, and Jenkins[11] presented the results of A increasing from 0.4 to 1.7 with $\mathrm{m}$ decreasing from 0.5 to 0.34 as grain size from 200 to $440 \mu \mathrm{m}$ and the value of the product Am increases from 0.2 to 0.6 with the remarkably stable value of $\mathrm{m}, 0.4$ of the grain size range $90-260 \mu \mathrm{m}$ at the $4 \mathrm{~m}$ depth and $90-135 \mu \mathrm{m}$ at the $7 \mathrm{~m}$ depth.

\subsection{The Concepts and Data for Analyses in This Study}

When storm waves reach the swell built profile, they are steep and arrive almost every second. Much water is thrown onto the beach face, which quickly becomes saturated, implying that the groundwater level is almost coincident with the beach face. Less water can percolate and, hence, the downwash almost equals the up-rush, causing beach face erosion. Sand-laden water then proceeds seawards and approaches deeper water, where its velocity is reduced and so causing its sedimentary load to be deposited. This material accumulates in the form of a bar parallel to the beach, which continuous to build up in the course of storm until the depth over it are sufficiently small for the incoming storm wave to be broken over it. At this stage, beach erosion essentially ceases. In the process of building up this bar and its subsequent seawards movement, distribution and sorting of sediment size across the bar mass has been reported, for example, as in Figure 10. There is difficult in defining the range of wave steepness $(\mathrm{H} / \mathrm{L})$ associated with storms, although it has commonly been accepted that steeper waves often produce a barred beach profile. As a coastal engineer, the criteria for the formation of bar and berm profiles and the guideline of sea dike designs need to be clarified. Japanese researchers (Kajima et al.[12] , Takeda[13], Sunamura and Horikawa[14], Sunamua and Maruyma[15]) have plotted $\mathrm{H}_{0} / \mathrm{L}_{0}$ versus $(\tan \beta)^{0.27}\left(\mathrm{D} / \mathrm{L}_{0}\right)^{0.67}$ and $\mathrm{H}_{\mathrm{b}} / \mathrm{gT}^{2}$ versus $\mathrm{H}_{0} / \mathrm{wT}$ and $\mathrm{H}_{0} / \mathrm{L}_{0}$ against $\left(\mathrm{H}_{0} / \mathrm{wT}\right) \tan \beta$, where "w" being the sediment fall velocity (Dean[16], Kraus and Larson[17], Larson[18], Larson and Kraus[4], and Dally[19]). Other large wave tank tests can be found in Vellinga[20]. The results by Takeda[13] and by Larson[18] are plotted in Figures 11 and 12, where H0 and L0 are wave height and wave length in deep sea; $\beta$, the beach slope; $\mathrm{Hb}$, the wave height of break wave; $\mathrm{D}$, the medium grain size in $\mathrm{mm}$; $\mathrm{g}$, the gravity acceleration and $\mathrm{T}$, the wave period. A search for suitable new dimensionless parameters to represent the beach profile change is a worthwhile task. To facilitate this work, the LWT (Large Wave Tank) data of US Army Corps of Engineers (abbreviated as "CE" being for Coastal Engineering Research Center) and Japanese Central research Institute of Electric Power Industry (abbreviated as "CRIEPI" data) are summarized and reanalyzed. 


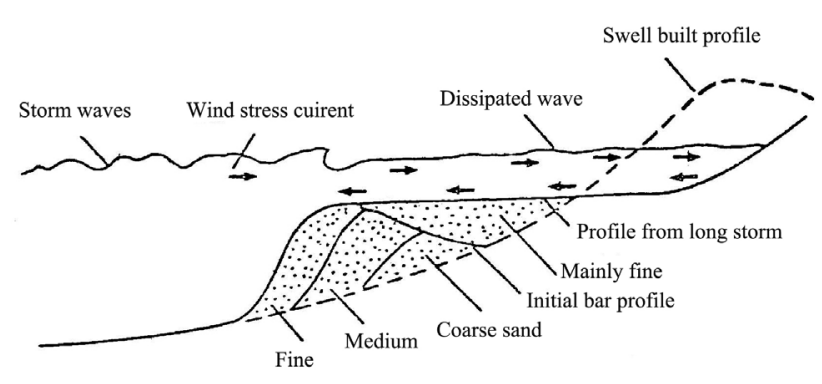

Figure 10. Definition of Beach Profile

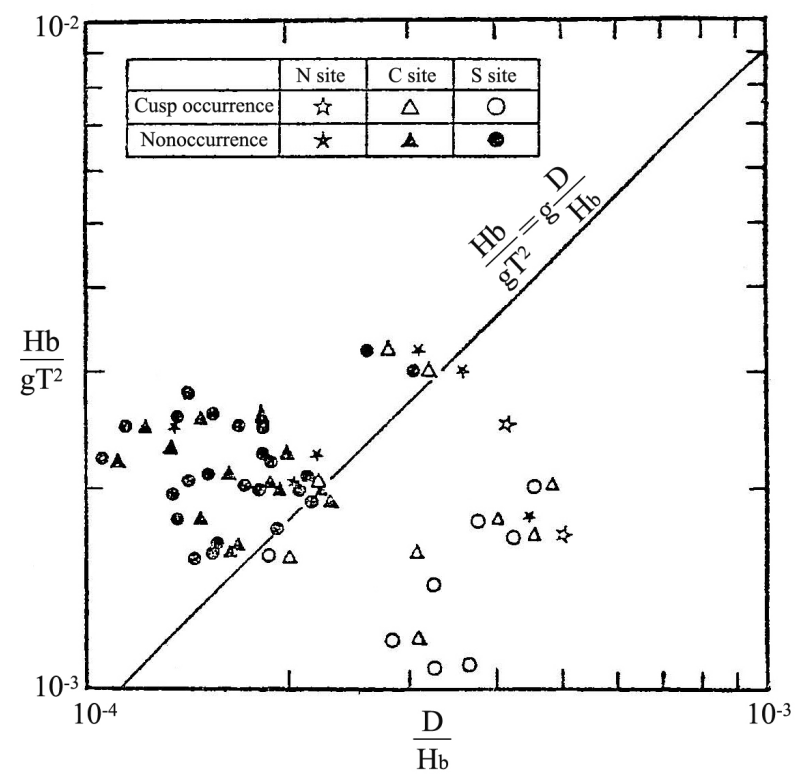

Figure 11. Bar and Berm Grouping by Takeda

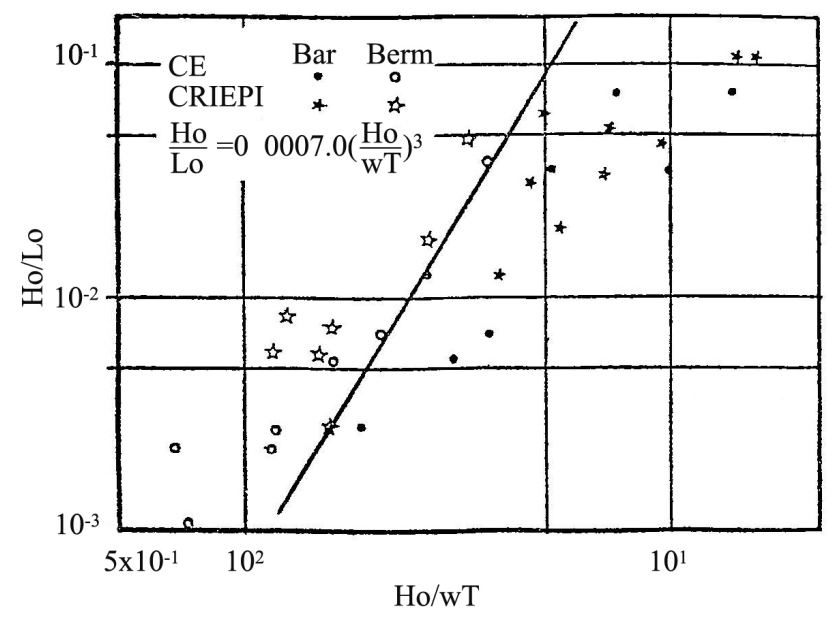

Figure 12. Bar and Berm Grouping by Larson

\subsection{The Results of this study of Bar-Berm Classification:}

The two independent data sets obtained in using LWT, referred to as CE and CRIEPI experiments respectively, were employed in this study. The 32 data entries were separated into two categories, being 18 data for bar profiles and the remaining 14 entries for berm predominated profiles.
Some of the pertinent physical quantities are collected from various reports and others from calculations by the authors. A summary of these basic data is collectively presented physical quantities are collected from various reports and others from calculations by the authors. A summary of these basic data is collectively presented in Tables 1 and 2.From re-analyzing these data, an alternative definition on storm wave condition can be clearly given, based on the dimensionless sediment fall velocity $\mathrm{Hb} / \mathrm{wT}$, evaluated at breaking condition.

For a mean grain size ds $(\mathrm{mm})$ with a fall velocity based on the assumption that the grain is a sphere relating the Reynolds number (wds/v) to the buoyancy index, B.

$$
\left[\left(\mathrm{r}_{\mathrm{s}} / \mathrm{r}\right)-1\right] \cdot \mathrm{gds} \mathrm{s}^{3} / \mathrm{v}=\mathrm{B}
$$

where $\mathrm{rs}=$ the specific weight of the solid grain; $\mathrm{r}=$ the specific weight of the fluid; $v=$ the fluid kinematic viscosity; the fall velocity, $w$ in water of common quartz is defined as:

$$
w=\left[\left(r_{s} / r\right)-1\right]^{0.7} d_{50}^{1.1} / 6 v^{0.4}
$$

with

$$
39<\mathrm{B}<104
$$

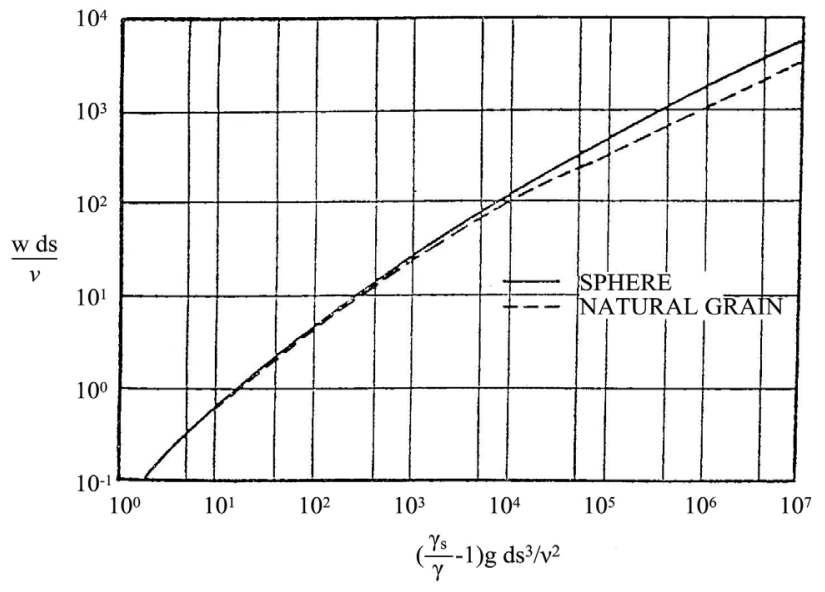

Figure 13. Relationship of Reynolds Number and Buoyancy Index

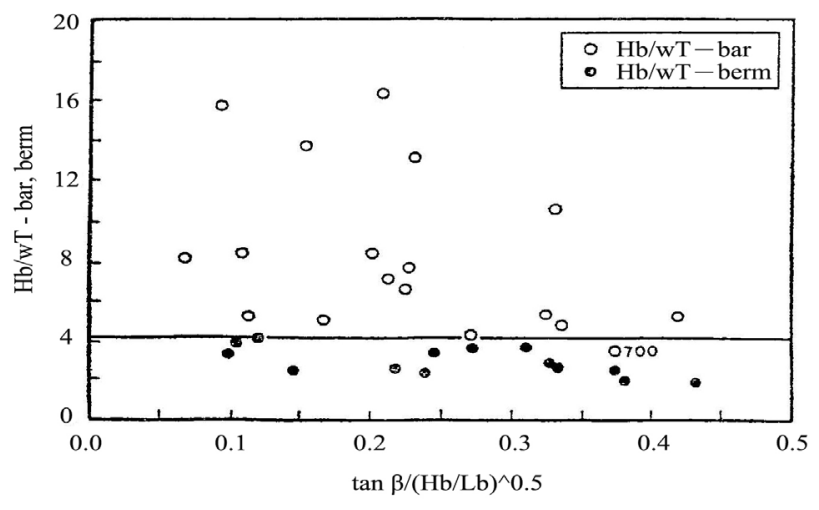

Figure 14. Bar and Berm Grouping by Luo

The relationship between Reynolds number and the index $\mathrm{B}$ is presented in Figure 13. The other dimensionless 
parameter denoting wave characteristics, such as, $\tan \beta /\left(\mathrm{H}_{\mathrm{b}} / \mathrm{L}_{\mathrm{b}}\right)^{1 / 2}$ is used to define the criterion of bar and berm. As shown in Figure 14 which plots: $\mathrm{H}_{\mathrm{b}} / \mathrm{wT}$ versus $\tan \beta /\left(\mathrm{H}_{\mathrm{b}} / \mathrm{L}_{\mathrm{b}}\right)^{1 / 2}$, a horizontal line at $\mathrm{Hb} / \mathrm{wT}=4.10$ can be clearly drawn for demarcating the bar/berm profiles, except for the data point representing case 700 in the $\mathrm{CE}$ experiment in which its water depth was decreased from $4.11 \mathrm{~m}$ to $3.81 \mathrm{~m}$ after $10 \mathrm{hrs}$ of running.

In Tables 1 and 2 , only $\mathrm{ds}, \mathrm{m}(=\tan \beta)$, wave height $\mathrm{H}$, wave period $\mathrm{T}$, water depth $\mathrm{h}$, deep water height $\mathrm{H} 0$, breaker height $\mathrm{Hb}$, a given temperature (for getting $v$ ), and the experimentally resulting beach profile are measured, the fall velocity, w, can be obtained from Figure 5 or Eq. (4), while hb, the breaker water depth, obtained by:

$$
\begin{gathered}
\mathrm{h}_{\mathrm{b}} / \mathrm{H}_{\mathrm{b}}={ }_{1 /\left[\mathrm{b}-\left(\mathrm{aH}_{\mathrm{b}} / \mathrm{gT}^{2}\right)\right]=\mathrm{f}(\mathrm{m}, \mathrm{T})} \\
\mathrm{a}=43.75(1-\mathrm{e}-19 \mathrm{~m}) \\
\mathrm{b}=1.56 /\left[\left(1+\mathrm{e}^{-19.5 \mathrm{~m}}\right)\right]
\end{gathered}
$$

$\mathrm{m}=\tan \beta=$ initial beach slope

$\mathrm{Cb}=\sqrt{\mathrm{gh}_{\mathrm{b}}}=$ celerity at the breaking wave

$\mathrm{L}_{\mathrm{b}}=\mathrm{C}_{\mathrm{b}} \cdot \mathrm{T}=$ Wavelength at breaking wave position

The above empirical relationships are derived in the Shoreline Protection of U.S.A. Manual by U.S. Army Crops of Engineers.[21].

By comparing the results in Figures 11, 12, and 14, the new relationship of Figure 14 in this study is quite easy and simple to clarify the beach profile of bar and berm.

\section{Criteria of Seawall Designs}

A linear system of equations for the run-up of breaking waves is developed by Massel [22]. This system is based on the application of the mild-slope equation in the deeper area, where waves are dispersive, while the linear equations of shallow water are applied close to the shoreline, where the water depth is a linear function of distance. The factor of dissipation in the shallow water equation has been formulated using its resemblance to the mild-slope equation for a non-permeable sea bottom. Transformation of waves on sandy beaches, their breaking, set-up and run-up are the main factors contributing to fluctuations in the water table and groundwater flow. In this paper, the run-up mechanisms have been studied using analytical models. In contrast to the standard models, the waves approaching the shoreline are assumed to be dispersive and the equivalence of the non-linear and linear solutions for the extreme characteristics of wave run-up, such as the height of

\begin{tabular}{|c|c|c|c|c|c|c|c|c|c|c|c|c|}
\hline $\begin{array}{l}\text { Case } \\
\text { No. } \\
\end{array}$ & $\begin{array}{c}\mathrm{ds} \\
(\mathrm{mm})\end{array}$ & $\mathrm{m}$ & $\begin{array}{c}\mathrm{H} \\
(\mathrm{m})\end{array}$ & $\begin{array}{c}\mathrm{T} \\
(\mathrm{sec})\end{array}$ & $\begin{array}{c}\mathrm{h} \\
(\mathrm{m})\end{array}$ & $\begin{array}{l}\mathrm{H}_{\mathrm{o}} \\
(\mathrm{m})\end{array}$ & $\begin{array}{l}\mathrm{H}_{\mathrm{b}} \\
(\mathrm{m})\end{array}$ & $\begin{array}{l}\mathrm{H}_{\mathrm{o}} / \mathrm{L}_{\mathrm{o}} \\
\left(\times 10^{3}\right) \\
\end{array}$ & $\mathrm{H}_{\mathrm{o}} / w \mathrm{~T}$ & $\begin{array}{c}\mathrm{H}_{\mathrm{o}} / \mathrm{ds} \\
\left(\times 10^{-3}\right) \\
\end{array}$ & $\begin{array}{l}\text { Profile } \\
\text { (E) }\end{array}$ & $\begin{array}{l}\text { Profile } \\
\text { (c) }\end{array}$ \\
\hline 100 & 0.22 & $1 / 15$ & 1.28 & 11.33 & 4.57 & 1.081 & 1.68 & 5.40 & 3.08 & 4.91 & bar & bar \\
\hline 200 & 0.22 & $1 / 15$ & 0.55 & 11.33 & 4.57 & 0.461 & 1.07 & 2.30 & 1.13 & 2.10 & berm & berm \\
\hline 300 & 0.22 & $1 / 15$ & 1.68 & 11.33 & 4.27 & 1.402 & 2.00 & 7.00 & 3.75 & 6.37 & bar & bar \\
\hline 400 & 0.22 & $1 / 15$ & 1.62 & 5.60 & 4.42 & 1.717 & 2.30 & 3.51 & 9.89 & 7.80 & bar & bar \\
\hline 500 & 0.22 & $1 / 15$ & 1.52 & 3.75 & 4.57 & 1.645 & 1.90 & 7.50 & 14.15 & 7.48 & bar & bar \\
\hline 600 & 0.22 & $1 / 15$ & 0.61 & 16.00 & 4.57 & 0.439 & 1.15 & 1.10 & 0.74 & 2.00 & berm & berm \\
\hline 700 & 0.22 & $1 / 15$ & 1.62 & 16.00 & 4.11 & 1.118 & 2.10 & 2.80 & 1.89 & 5.08 & bar & ${ }^{*}$ berm \\
\hline & & & & & (3.81) & & & & & & & \\
\hline 101 & 0.40 & $1 / 15$ & 1.28 & 11.33 & 4.57 & 1.081 & 1.80 & 5.40 & 1.62 & 2.70 & berm & berm \\
\hline 201 & 0.40 & $1 / 15$ & 0.55 & 11.33 & 4.57 & 0.461 & 1.90 & 2.30 & 0.69 & 1.15 & berm & berm \\
\hline 301 & 0.40 & $1 / 15$ & 1.68 & 11.33 & 4.27 & 1.402 & 2.40 & 7.00 & 2.17 & 3.51 & berm & berm \\
\hline 401 & 0.40 & $1 / 15$ & 1.62 & 5.60 & 4.42 & 1.717 & 2.40 & 3.51 & 5.57 & 4.29 & bar & bar \\
\hline 501 & 0.40 & $1 / 15$ & 1.52 & 3.75 & 4.57 & 1.645 & 1.60 & 7.50 & 7.98 & 4.11 & bar & bar \\
\hline 701 & 0.40 & $1 / 15$ & 1.62 & 16.00 & 3.81 & 1.118 & 1.95 & 2.80 & 1.18 & 2.80 & berm & berm \\
\hline 801 & 0.40 & $1 / 15$ & 0.76 & 3.75 & 4.57 & 0.827 & 0.76 & 3.77 & 3.74 & 2.07 & berm & berm \\
\hline 901 & 0.40 & $1 / 15$ & 1.34 & 7.87 & 3.96 & 1.246 & 2.00 & 1.29 & 2.68 & 3.12 & bar & bar \\
\hline
\end{tabular}
maximum run-up and the velocity of run-up, are used.

Table 1. Large Wave Tank Data of U.S. Army of Engineers (CE)

(1) Profile (E) the experimental data; (c) the analytical results.

(2) The "h" of Case No. 700 by 3.81 after 10 hours. 
Table 2. Large Wave Tank Data of CRIEPI in Japan

\begin{tabular}{|c|c|c|c|c|c|c|c|c|c|c|c|c|}
\hline $\begin{array}{l}\text { Case } \\
\text { No. }\end{array}$ & $\begin{array}{c}\mathrm{ds} \\
(\mathrm{mm})\end{array}$ & $\mathrm{m}$ & $\begin{array}{c}\mathrm{H} \\
(\mathrm{m})\end{array}$ & $\begin{array}{c}\mathrm{T} \\
(\mathrm{sec})\end{array}$ & $\begin{array}{c}\mathrm{h} \\
(\mathrm{m})\end{array}$ & $\begin{array}{c}\mathrm{H}_{\mathrm{o}} \\
(\mathrm{m})\end{array}$ & $\begin{array}{c}\mathrm{H}_{\mathrm{b}} \\
(\mathrm{m})\end{array}$ & $\begin{array}{l}\mathrm{H}_{\mathrm{o}} / \mathrm{L}_{\mathrm{o}} \\
\left(\times 10^{3}\right)\end{array}$ & $\mathrm{H}_{\mathrm{o}} / w \mathrm{~T}$ & $\begin{array}{c}\mathrm{H}_{\mathrm{o}} / \mathrm{ds} \\
\left(\times 10^{-3}\right)\end{array}$ & $\begin{array}{c}\text { Profile } \\
\text { (E) }\end{array}$ & $\begin{array}{l}\text { Profile } \\
\text { (c) }\end{array}$ \\
\hline $1-1$ & 0.47 & $1 / 20$ & 0.44 & 6.0 & 4.5 & 0.461 & 0.95 & 8.20 & 1.202 & 98.10 & berm & berm \\
\hline $1-3$ & 0.47 & $1 / 20$ & 1.05 & 9.0 & 4.5 & 0.948 & 1.40 & 7.50 & 1.648 & 2.02 & berm & berm \\
\hline $1-8$ & 0.47 & $1 / 20$ & 0.81 & 3.0 & 4.5 & 0.852 & 0.85 & 6.07 & 4.444 & 1.81 & bar & bar \\
\hline $2-1$ & 0.47 & $3 / 100$ & 1.80 & 6.0 & 3.5 & 1.758 & 1.94 & 3.13 & 4.585 & 3.74 & bar & bar \\
\hline $2-2$ & 0.47 & $3 / 100$ & 0.86 & 9.0 & 3.5 & 0.733 & 1.54 & 5.80 & 1.275 & 1.56 & berm & berm \\
\hline $2-3$ & 0.47 & $3 / 100$ & 0.66 & 3.1 & 3.5 & 0.709 & 0.80 & 4.73 & 3.579 & 1.51 & berm & berm \\
\hline $3-1$ & 0.27 & $1 / 20$ & 1.07 & 9.1 & 4.5 & 1.040 & 0.88 & 7.40 & 3.294 & 3.85 & bar & bar \\
\hline $3-2$ & 0.27 & $1 / 20$ & 1.05 & 6.0 & 4.5 & 2.101 & 1.58 & 1.96 & 5.288 & 4.08 & bar & bar \\
\hline $3-3$ & 0.27 & $1 / 20$ & 0.81 & 12.0 & 4.5 & 0.651 & 1.47 & 2.90 & 1.563 & 2.41 & berm & berm \\
\hline $3-4$ & 0.27 & $1 / 20$ & 1.54 & 3.1 & 4.5 & 1.619 & 1.50 & 1.08 & 15.050 & 6.00 & bar & bar \\
\hline $4-1$ & 0.27 & $3 / 100$ & 0.31 & 3.5 & 3.5 & 0.340 & 0.50 & 1.78 & 2.080 & 1.26 & berm & berm \\
\hline $4-2$ & 0.27 & $3 / 100$ & 0.97 & 4.5 & 4.0 & 1.058 & 1.27 & 3.35 & 6.776 & 3.92 & bar & bar \\
\hline $4-3$ & 0.27 & $3 / 100$ & 1.51 & 3.1 & 4.0 & 1.604 & 1.52 & 1.07 & 14.910 & 5.94 & bar & bar \\
\hline $5-1$ & 0.27 & $1 / 50$ & 0.29 & 5.8 & 3.5 & 0.299 & 0.63 & 5.70 & 1.486 & 1.11 & berm & berm \\
\hline $5-2$ & 0.27 & $1 / 50$ & 0.74 & 3.1 & 3.5 & 0.799 & 0.89 & 5.33 & 3.970 & 2.96 & bar & bar \\
\hline $6-1$ & 0.27 & $1 / 10$ & 1.66 & 5.0 & 4.0 & 0.778 & 1.91 & 4.56 & 10.250 & 6.59 & bar & bar \\
\hline $6-2$ & 0.27 & $1 / 10$ & 1.12 & 7.5 & 4.5 & 1.097 & 1.42 & 1.25 & 4.215 & 4.06 & bar & bar \\
\hline
\end{tabular}

Understanding and forecasting tsunami wave run-up is very important in mitigating tsunami hazards. The bed stress under wave motion governs viscous wave damping and sediment transport processes, which change the coastal morphology. One of the most common methods used for simulation is the shallow water equation (SWE) model, often used with a Manning-style approach for modeling bottom friction. Boundary-layer approaches provide better information regarding bed stress, particularly since they are also valid for unsteady flows. In this study, a simulation of wave run-up is carried out by simultaneous coupling of the SWE model with the $\mathrm{k}-\omega$ model by Adityawan, et al [23]

The k- $\omega$ model is used near the flow boundary at the bottom, only for assessing the boundary layer shear stress. Free stream velocity and calculations of the free surface evolution are obtained from the SWE model. The new method is found to increase the computational accuracy and physical realism compared to the conventional Manning method. Comparison of bed shear stresses shows that the new method is able to accommodate the effect of deceleration, which leads to sign changes and a phase shift between the free stream velocity and the bed stress. Furthermore, it is found that during the run-up and run-down process, bed stress in the direction of leaving the shoreline is more dominant.

Wave run-up, wave set-up and wave run-down are determined by using the residence time in the form of a duration curve. Schuttrumpf, et al [24] introduced this new method by considering the totality of a run-up series without considering individual run-up events separately. By using the residence time concept, wave run-up is not any more a timeless event but can be described as a time dependent variable. The residence time concept has been used for regular and random waves. This concept is particularly useful for random waves, because there is no need to count the number of waves loading a dike.

The force and velocity acting on the seawall, especially at the toe, has a quite sensitive relationship with the specific parameter of $(\mathrm{R} / \mathrm{H} 0)$, called dimensionless wave run-up values, and this specific run-up height, $\mathrm{R}$ (the maximum and the significant), correlating to the duration of time series of wave action and its corresponding spectrum, Iribarren number, the angle of the structure slope and the wave steepness.

. An interesting aspect from table is that dimensionless wave run-up values increase when the mean water level decreases. The lower the exceed probability, the more the dimensionless wave run-up values increase. Wave run-up levels are slightly higher during rising tide than during receding tide. This may be due to tidal currents and/or the asymmetric tide. A part of the explanation why dimensionless wave run-up values depend on the water level in front of the structure can be found within the fact that wave heights are lower when lower water depths are considered, so for constant $\mathrm{R}$ the ratio (R/H0) becomes larger when $\mathrm{H}$ decreases. However, when looking at the $\mathrm{R}$ 
values themselves, these increase also when water depth decreases. This phenomenon could be explained by the fact that at lower water levels wave run-up takes place at a lower part of the slope. The lower porosity of the armour layer at lower levels (due to the settlement of the armour units during the lifetime of the seawalls) may cause larger wave run-up. Moreover, at lower water levels, the water depth is less, leading to breaking waves with higher wave run-up.

Based on the data of Muttray, M. et al [25]; Buccino, M. et al [26]; Troch, ir. P. et al [27]; Rouck, J. De. et al [28]; Troch, P. [29]; Hsiao, S. C. et al [30]; Neelamani, S. [31]; Setyandito, O. et al [32]; Wei, Y. X. et al [33]; Holger Sch"uttrumpf, [34], and Tsai et al [35], the following set of equation can be used as the design reference:

Down-rushing flow on a sea dike toe induced by waves are summarized and reanalyzed by statistics, the new sets of sea dike design guideline are:

$$
\begin{aligned}
& \left(\frac{\mathrm{H}_{\mathrm{b}}}{\mathrm{gT}^{2}}\right)^{3 / 2} \geq 0.090\left(\mathrm{~h}_{\mathrm{b}} / \mathrm{gT}^{2}\right)^{1.261}(\tan \beta)^{0.582} \\
& \mathrm{U}+\mathrm{max} / \mathrm{g}^{0.25} \mathrm{H}_{\mathrm{b}}{ }^{0.75} \mathrm{~T}^{-0.50} \\
& =0.020\left[\mathrm{R} / \frac{\mathrm{H}_{\mathrm{b}}{ }^{3 / 2}}{\sqrt{\mathrm{gT}^{2}}}\right]^{0.608}\left(\frac{\mathrm{h}_{\mathrm{b}}}{\mathrm{gT}^{2}}\right)^{-0.078}\left(\frac{\mathrm{H}_{\mathrm{b}}}{\mathrm{gT}^{2}}\right)^{-0.390}(\tan \beta)^{-0.392}
\end{aligned}
$$

$$
\begin{aligned}
& \mathrm{U}-\max / \mathrm{g}^{0.25} \mathrm{H}_{\mathrm{b}}^{0.75} \mathrm{~T}^{-0.50} \\
& =0.0195\left[\mathrm{R} / \frac{\mathrm{H}_{\mathrm{b}}{ }^{3 / 2}}{\sqrt{\mathrm{gT}^{2}}}\right]^{-0.076}\left(\frac{\mathrm{h}_{\mathrm{b}}}{\mathrm{gT}^{2}}\right)^{-0.209}\left(\frac{\mathrm{H}_{\mathrm{b}}}{\mathrm{gT}^{2}}\right)^{-0.302}(\tan \beta)^{-0.262}
\end{aligned}
$$

$$
\begin{aligned}
& \overline{\mathrm{P}}+\max / \rho \mathrm{g}^{0.25} \mathrm{H}_{\mathrm{b}}{ }^{1.5} \mathrm{~T}^{-1} \\
& =0.952\left[\mathrm{R} \frac{\mathrm{H}_{\mathrm{b}}{ }^{3 / 2}}{\sqrt{\mathrm{gT}^{2}}}\right]^{0.836}\left(\frac{\mathrm{h}_{\mathrm{b}}}{\mathrm{gT}^{2}}\right)^{0.243}\left(\frac{\mathrm{H}_{\mathrm{b}}}{\mathrm{gT}^{2}}\right)^{-0.016}(\tan \beta)^{0.221}
\end{aligned}
$$

$$
\begin{aligned}
& \overline{\mathrm{P}}-\max / \rho g^{0.25} \mathrm{H}_{\mathrm{b}}{ }^{1.5} \mathrm{~T}^{-1} \\
& =0.202\left[\mathrm{R} / \frac{\mathrm{H}_{\mathrm{b}}{ }^{3 / 2}}{\sqrt{\mathrm{gT}^{2}}}\right]^{0.295}\left(\frac{\mathrm{h}_{\mathrm{b}}}{\mathrm{gT}^{2}}\right)^{-0.128}\left(\frac{\mathrm{H}_{\mathrm{b}}}{\mathrm{gT}^{2}}\right)^{-0.422}(\tan \beta)^{-0.916}
\end{aligned}
$$

\section{Conclusions and Applications}

The new relationship for distinguishing bar and berm is convenient and applicable. For a given beach slope, m; water depth, h; wave height, $\mathrm{H} 0$; the variables of $\mathrm{Hb}, \mathrm{hb}$, are obtained; furthermore, the given beach profile can be told whether a bar (erodible profile) or a berm (deposited profile). The design criteria of the steeper slope of seawalls owns wider range of the incident wave conditions to produce down-rushing flow to the toe. The intensity of the down-rushing flow of the milder slope seawalls is weaker than that of the steeper slope. The dimensionless value of the maximum flow velocity and its pressure on the toe are increasing with the relative height of the wave run-up.

As we have seen, hard stabilization can be used to maintain the shoreline, but this is both expensive and can have negative consequences (often unforeseen). Dams (which block the flow of sediments to the shoreline) can be removed, but the dams themselves provide a variety of benefits that we would have to forego. Millions of dollars are spent by cities on a regular basis to replace lost sand. Sand for "beach re-nourishment" can be trucked in from deserts or behind dams, or dredged from the ocean floor. It may only stay on the beach for as little as a year, so this is an ongoing expense. Careful research is needed to estimate how long it will remain. When possible, the best strategy is to help the sand "bypass" obstacles like long jetties: remove the sand from one side and carry it to the other side. Another option is to do nothing, let nature takes its course, and plan for the changes (to adapt). For example, shoreline buildings can be built so that they can be moved when necessary. People who live on shifting barrier islands are building these kinds of homes more and more often.

All and all, I would argue that there is no one right answer (certainly one right answer that applies in all circumstances). Each choice involves expensive trade-offs; some people will "win" (benefit), and some people will "lose" (suffer).

Climate change and effects such as sea-level rise have global implications and will increasingly affect the entire nation. To recognize how the different coastal environments will respond to future climate and sea-level change is a major challenge. In addition, as highlighted in human actions and policy decisions also substantially influence the evolution of the coast. A significant emphasis is placed on developing linkages between scientists, policy makers, and stakeholders at all levels, so that information can be shared and utilized efficiently and effectively as sea-level rise mitigation and adaptation plans evolve.

\section{REFERENCES}

[1] Sunamura, T. and K. Horikawa, " Two-dimensional beach transformation due to waves," Proceedings of the 14th Conference on Coastal Engineering, ASCE, pp. 920-938 (1974).

[2] Bagnold, R. A. "Sand movement by waves: Some small-scale experiments with sand of very low density", J. Inst. Civ. Eng., 27, 447-469, 1947.

[3] Keulegan, G. H., "An experimental study of submarine sand bar”, Tech. Rep. 3, 40 pp., Beach Erosion Board, U. S. Army Corps of Engineering Washington, D. C., 1948. 
[4] Larson, M., and N. C. Kraus, "SBEACH: Numerical model for simulating storm-induced beach change; empirical foundation and model development", Tech. Rep. CERC-89-9, 256 pp., Appe3ndices A-B, Coastal Eng. Res. Cent., Waterway. Experiment Sta. U. S. Army Corps of Eng., Vicksburg, Miss., 1989.

[5] Dean, R. G., "Equilibrium beach profile: Characteristics and application", J. Coastal Res., 7(1), 53-84, 1991.

[6] Shepard, F. P., and E. C. LaFond, "Sand movements along the Scripps Institution pier:, Am. J. Sci., 238, 272-285, 1940.

[7] Evans, O. F., "The low and ball of the eastern shore of Lake Michigan:, J. Geol., 48, 476-511, 1940.

[8] Keulegan, G. H., and W. C. Krumbeun, " Stable configuration of bottom slope in a shallow sea and its bearing on geological processes", Eos Trans. AGU, 30(6), 855-861, 1949.

[9] Bruun, P., "Coast erosion and the development of beach profile", Tech. Memo 44, 79 pp., Beach Erosion Board, U. S. Army Corps of Eng., Washington, D. C. 1954.

[10] Dean, R. G., "Equilibrium beach profiles: U. S. Atlantic and Gulf coasts:, Ocean Eng. Rep. 12, 45 pp. +appendix, Univ. of Del., New York, 1977.

[11] Inman, D. L., M. H. Elwany, and S. A. Jenkins, "Shorerise and bar-berm profiles on ocean beaches", Scripps Institution of Oceanography, UC San Diego, 1993.

[12] Kajrma, R., T. Shimizu, K.. Maruyama, and S. Saito, "Experiments on beach profile change with a large wave flume", Proc. 18th International. Conf. Coastal Engineering, ASCE, Vol. II, 1365-1404. 1987

[13] Takeda, I., " Beach changes by waves", Science Reports, Inst. Geo-science, University of Tasukuba, Section A, Vol.5, 29-63, 1984.

[14] Sunamura, T. and K. Horikawa, "Two dimensional beach transformation due to waves", Proc. 14th International. Conf. Coastal Engineering. ASCE, Vol II, 920-938, 1984.

[15] Sunamura, T. and K..Maruyama, "Wave-induced geomorphic response of eroding beaches-with special reference to seaward migrating bars", Proc. Coastal Sediments, 1987, ASCE, Vol. I. 788-801, 1987.

[16] Dean, R.G., "Heuristic models of sand transport in toe surf zone", Proc. 1st Aust. Conf. Coastal and Ocean Engineering, Sydney, 208-214, 1937.

[17] Kraus, N. C. and M. Larson, "Beach profile change measured in the tank for large waves", 1956-1957 and 1962. Waterways Expt. Station, US, Army Corps of Engineers. Tech. Report CERC-88-6, 1988.

[18] Larson, M., "Quantification of beach profile change", Dept. Water Resources Engineering, University of Lund, Sweden, Report 1008, 1988.

[19] Dally, W.R., "Long-shore bar formation surf beat or undertow?", Proc. Coastal Sediments, ASCE, Vol. I, 71-86, 1987.

[20] Vellinga, P., "Beach and dune erosion during storm surges", Coastal Engineering, Vol. 6, 361-387, 1982.

[21] U.S. Army Crops. of Engineering, "Manual of shoreline Protection”, 1984.
[22] Massel, S. R., "Run-up of dispersive and breaking waves on beaches", Oceanologia, 43 (1), 61-97, Institute of Oceanology PAS, 2001.

[23] Adityawan, M. B. and H. Tanaka, "Bed stress assessment under solitary wave run-up", Earth Planets Space, 64, 945-954, 2012.

[24] Schuttrumpf, H., H. Bergmann, and H-H. Dette, "The concept of residence time for the description of Wave Run-Up, Wave Set-up and Wave Run-Down", the Coastal Engineering Research Unit "SFB 205", Deutsche Forschungsgemeinschaft (DFG), Bonn, Coastal Engineering, 1994.

[25] Muttray, M., H. Oumeraci, and E. Oever, "Wave Reflection and wave run-up at rubble mound breakwaters", coastal engineering research, 2006.

[26] Buccino, M., M. Calabrese, F. Ciardulli, P. Di Pace, and G.R. Tomasicchio, "One layer concrete armor units with a rock-like skin: wave reflection and run-up", Journal of Coastal Research, SI 64, 469 - 473, Proceedings, Poland, 2011.

[27] Troch, P., Ing. H. Oumeraci, and Ing. A. Kortenhaus, "Analysis of wave run-up and impact processes on smooth sea dikes under 3D aspects", Universiteit Gent, Section Coastel Engineering, Final Project, 2006.

[28] Rouck, J. De., B. V. de Walle, P. Troch, J. V. der Meer, L. V. Damme, "Wave run-up on the Zeebrugge rubble mound breakwater: full-scale measurement results", Journal of Coastal Research, 23(3), 577-583, West Palm Beach, Florida, 2007.

[29] Troch, P, "Experimental study and numerical modelling of pore pressure attenuation inside a rubble mound breakwater", Paper awarded the international PIANC G. Willems Prize Competition, 2001.

[30] Hsiao, S C, T W Hsu, T C Lin, and Y. H Chang, "On the evolution and run-up of breaking solitary waves on a mild sloping beach", Coastal Engineering 55 975-988, Elsevier, 2008.

[31] Neelamani, S., "Subareal wave pressure, layer thicknesses, run-up and run-down velocity on seawall", Indian Journal of Marine Science, Vol 34(3), 299-309, 2005.

[32] Setyandito, O., Nizam, N. Yuwono, R. Triatmadja, and P. Pandin," The profile stability on the artificial sand beach nourishment", International Journal of Civil \& Environmental Engineering IJCEE-IJENS Vol: 12 No: 02, 2012.

[33] WEI, y. x., d. t. Wang, and q. j. Liu, "Application of artificial neural network to calculation of solitary wave run-up", Water Science and Engineering, 3(3): 304-312, doi:10.3882/j.issn.1674-2370.2010.03.006, 2010.

[34] Sch"uttrumpf, H., " Wave run-up and wave overtopping at armored rubble slopes and mounds", Chapter 15, EurOtop Overtopping Manual, 2007.

[35] Tsai, c.p., j.s.Wang, and c. Lin, "Down-rushing flow on a sea dike induced by waves", 17th Ocean Engineering Conference Tainan Taiwan, 1995. 